\title{
Arsenic Removal from Zimapan Contaminated Water Monitored by the Tyndall Effect
}

\author{
Eunice Vera-Aguilar'1, Eduardo López-Sandoval2, Juan José Godina-Nava3, \\ Mariano Enrique Cebrián-García ${ }^{1}$, Octavio López-Riquelme³, \\ Miguel Angel Rodríguez-Segura ${ }^{3}$, Blanca Estela Zendejas-Leal3 ${ }^{3}$ Carlos Vázquez-López ${ }^{3}$ \\ ${ }^{1}$ Departamento de Farmacología, Centro de Investigación y de Estudios Avanzados del IPN, México D.F., \\ México \\ ${ }^{2}$ Departamento de Ciências Exatas e Tecnológicas, Universidade Estadual de Santa Cruz, Ilhéus, Brazil \\ ${ }^{3}$ Departamento de Física, Centro de Investigación y de Estudios Avanzados del IPN, México D.F., México \\ Email: ${ }^{*}$ cvlopez@fis.cinvestav.mx
}

Received 27 February 2015; accepted 19 May 2015; published 22 May 2015

Copyright (C) 2015 by authors and Scientific Research Publishing Inc.

This work is licensed under the Creative Commons Attribution International License (CC BY). http://creativecommons.org/licenses/by/4.0/

(c) (i) Open Access

\section{Abstract}

In Zimapan Valley, Mexico, up to $1.1 \mathrm{mg} \cdot \mathrm{L}^{-1}$ of arsenic concentrations have been detected in deep wells that are used as drinking water supply for almost 39,000 people, which could have been exposed to levels higher than $10 \mu \mathrm{g} \cdot \mathrm{L}^{-1}$ of arsenic, the maximum level recommended by the World Health Organization. Chronic consumption of water contaminated with arsenic can cause several diseases, including cancer. For it, the implementation of practical and economical methods to remove arsenic from drinking water is crucial to protect the population health. In this work, an electrochemical method to remove arsenic from drinking water is described. The process, monitored by Tyndall effect, utilizes $\mathrm{Cu}^{2+}$ and $\mathrm{Zn}^{2+}$ ions from a brass electrode in an electrochemical cell with water as electrolyte. Results show that the EC process reduces the concentration of the arsenic diluted in Zimapan water to a level below the limit of detection of the atomic absorption spectrophotometer employed. Arsenic was removed through the formation of $\mathrm{Cu}$ and $\mathrm{Zn}$ arsenic compounds. $\mathrm{Cu}^{2+}$ and $\mathrm{Zn}^{2+}$ ions form a hydroxide and eventually polycrystalline precipitation of kottigite and cornubite complexes (identified by energy-dispersive X-ray spectroscopy and X-ray diffraction), which are then filtered to eliminate the precipitated arsenic compounds.

\section{Keywords}

Arsenic Removal, Turbidity, Tyndall Effect, Groundwater Arsenic-Contamination,

\footnotetext{
${ }^{*}$ Corresponding author.
} 


\section{Electro-Flocculation, Brass Electrodes}

\section{Introduction}

Arsenic is a toxic metalloid element common on the earth surface, soils, rocks, water and living organisms. It is present throughout the Earth's crust in concentrations of $1.7 \mathrm{mg} \cdot \mathrm{Kg}^{-1}$ [1] found in sedimentary, igneous and metamorphic rocks [2]. A combination of natural processes, including weathering and erosion, biological activity, and mainly volcanic eruptions is the main source of arsenic in environment [3]-[6]. Besides, human activities such as mining, combustion of fossil fuels, the use of arsenical pesticides and herbicides in agriculture, crop desiccants, arsenic-based additives for livestock feed, and arsenic use for wood preservation have an additional significant environmental and health impact, because it alters the natural flux and concentrations of arsenic [4].

Although humans can be exposed to arsenic through different pathways like air, food or soil, arsenic contaminated drinking water represents the major threat of all arsenic sources to human health, contributing mainly to the incidence of Chronic Endemic Regional Hydroarsenicism [7]. Toxicity of arsenic depends on the form it is found in nature; it can be present in different oxidation states ( -3 Arsine, +1 Arsonium Metals, +3 Arsenites, +5 Arsenates, 0 Elemental Arsenic) [3] [5]. Those compounds with +3 oxidation state are more toxic than compounds with +5 oxidation state, and inorganic arsenic compounds show higher toxicity than organic ones [5]. Arsenic organic compounds are found in food and marine organisms while inorganic arsenic compounds are found in minerals and in many aquifers, where they accumulate by means of natural processes [8]. In several regions of the world, aquifer water is used for drinking purposes. It represents an increased risk to develop serious diseases [3] [9]; since soluble arsenic compounds are extremely toxic [2] [3].

Chronic arsenic exposure affects mainly those organs involved in absorption, accumulation and excretion of arsenic [10]. Ingestion of high doses of arsenic leads to dermal pathologies, gastrointestinal damage, alterations in cardiovascular and nervous systems function, bone marrow depression, haemolysis, hepatomegaly, melanosis, polyneuropathy, encephalopathy and eventually death [3]. Among other effects, arsenic also has an adverse impact on the immune system [3] [10] [11]. Long-term intake of drinking water contaminated with arsenic increases the risk of developing different types of cancer, including skin, lung, bladder and kidney cancer [10][14]. In fact, it has been shown that arsenic can cause several alterations in the DNA [10]-[15], making arsenic an important carcinogen [9].

Concentrations of arsenic in natural waters vary over several orders of magnitude, ranging from $0.5 \mu \mathrm{g} \cdot \mathrm{L}^{-1}$ to more than $5000 \mu \mathrm{g} \cdot \mathrm{L}^{-1}$ [4] [16]. Arsenic concentrations in groundwater are typically below $10 \mu \mathrm{g} \cdot \mathrm{L}^{-1}$. In areas with geological activity and those with mining activities, arsenic has elevated concentrations reaching up to 3 $\mathrm{mg} \cdot \mathrm{L}^{-1}$; consequently, groundwater could result highly contaminated [3] [11]. Arsenic content in major problem aquifers ranges in 1 - $20 \mathrm{mg} \cdot \mathrm{Kg}^{-1}$ [4]. Groundwater with high arsenic concentrations enough to constitute a menace to human health has been reported in Bangladesh, India, Taiwan, Thailand, China, Hungary, Nepal, Myanmar, Vietnam, Argentina, Chile and Mexico. The scale of the problem represents almost 137 million people from more than 70 countries. They could have been exposed to drinking water containing more than the World Health Organization [WHO], and US Environmental Protection Agency (EPA) recommended a maximum of $10 \mu \mathrm{g} \cdot \mathrm{L}^{-1}$ content of arsenic [3] [17]-[19].

In Mexico, several regions with sources of drinking water contaminated with more than $50 \mu \mathrm{g} \cdot \mathrm{L}^{-1}$ of arsenic have been found, mainly in the north and center of the country [4] [16] [20]. The Comarca Lagunera represents the major health problem for the country with 400,000 inhabitants exposed to high levels of arsenic and fluoride in drinking water [4] [16] [21]. People in this central arid region of the country depend on groundwater as sources for drinking water [23]. Nevertheless, the health potential risk related to the consumption of contaminated water could be higher since almost $75 \%$ of drinking water in the country comes from groundwater sources [21].

Zimapan (Hidalgo state, Mexico, $20^{\circ} 40^{\prime} \mathrm{N}$ and $99^{\circ} 22^{\prime} \mathrm{N}$ ), in the center of the country, is one of the arid regions characterized by its high levels of arsenic in groundwater: $1.097 \mathrm{mg} \cdot \mathrm{L}^{-1}$ [21]. This contamination comes from the oxidation of arsenic-bearing minerals that pollute the deeper waters. In addition, there is an anthropogenic contamination from the mining activities in the region [21]-[23]. In Zimapan, water is a scarce resource, and population, estimated at 39,000 [24], totally depends to survive on groundwater. Water with more than 0.3 
$\mathrm{mg} \cdot \mathrm{L}^{-1}$ of arsenic is widely consumed in this region; several health problems related to chronic exposure to high levels of arsenic have been found [21] [23].

An environmental and public health problem on a global scale is the arsenic contamination of groundwater. Therefore, attention to arsenic contamination is growing today due to the public health problems arising around the world caused by groundwater highly enriched with this ubiquitous element [4] [25] [26]. Different technologies for the treatment of groundwater have been developed to remove arsenic from laboratory and field conditions [11] [27]. Almost all technologies for arsenic removal depend on two types of interactions: 1) Coulombic or ion-exchange interactions based on negative charges of $\mathrm{As}^{+5}$ oxyanions; 2) acid-base interactions of $\mathrm{As}^{+5}$ and $\mathrm{As}^{+3}$ [11] [27]. Many of these techniques are at the experimental stage, and some have not been demonstrated at large scale, continuing in an experimental phase. Besides, although some processes may be technically viable, their cost could be considerably high to make them prohibitive [11].

In this paper, a low-cost electrochemical method (EC) is proposed. The process utilizes $\mathrm{Zn}^{2+}$ and $\mathrm{Cu}^{2+}$ ions from brass electrodes in an electrochemical cell with the test water as the electrolyte and a power supply as the energy source. The $\mathrm{Zn}^{2+}$ and $\mathrm{Cu}^{2+}$ ions form a hydroxide, and eventually crystalline precipitation of minerals kottigite and cornubite complexes, which are then filtered to remove the arsenic content. The EC process was monitored by turbidity measurements and the chemical species were identified by energy dispersive X-ray spectroscopy (EDS) and X-ray diffraction techniques (XRD).

\section{Materials and Methods}

Procedures carried out in this work can be summarized as follows: 1) obtaining and preparation of aqueous samples; 2) EC removal of $\mathrm{As}^{+5}$ content; 3) monitoring $\mathrm{As}^{+5}$ content in the water sample by a modified Crecelius method of quantification; 4) monitoring the electrical current and of the light scattered from the aqueous samples produced by gradual flocculation using the Tyndall effect method; 5) quantification of $\mathrm{Zn}$ and $\mathrm{Cu}$ compounds obtained from the generated floccules. In Figure 1 these procedures are described.

\subsection{Water Samples}

In order to test the EC method developed to remove As, two types of water samples were used, as indicated in Table 1:

a) Sample A (contaminated water, problem sample). Water from a contaminated well in Zimapan, Hidalgo, Mexico was obtained to perform the study. The initial concentration of As of this sample was determined to be $249.3 \mu \mathrm{g} \cdot \mathrm{L}^{-1}$ (see methods below for quantification of As). Since this sample showed high turbidity, the suspended particles in the water were filtered using Millipore (Billerica, MA, USA) sterile membrane filter with pore size of $0.45 \mu \mathrm{m}$. By means of filtration, $75.2 \%$ of the total As was removed to get a final concentration of $61.9 \mu \mathrm{g} \cdot \mathrm{L}^{-1}$. The filtrated solution was treated by the EC method for As removal.

b) Sample B (artificially contaminated tap water). For comparison purpose, tap water from Mexico City was artificially contaminated with As $\left(\mathrm{Na}_{2} \mathrm{HAsO}_{4} \cdot 7 \mathrm{H}_{2} \mathrm{O}\right.$; Sigma-Aldrich; $99 \%$ purity) at a concentration of 500 $\mu \mathrm{g} \cdot \mathrm{L}^{-1}$.

\subsection{EC Method}

The EC method to remove inorganic As from water consisted in submerging two brass pipeline pieces with 2.54 $\mathrm{cm}$ in diameter and $11.76 \mathrm{~cm}$ length. These pipelines were sealed in their extremes and used as electrodes. The elementary composition of the electrodes was $62 \% \mathrm{Cu}, 34 \% \mathrm{Zn}, 3 \% \mathrm{O}$, and $1 \% \mathrm{Al}$, as obtained by means of EDS. A bias of 3 volts was applied to the electrodes once they were immersed in $500 \mathrm{~mL}$ of each water sample in a beaker. The elapsed time of the EC treatment was 60 min. Besides, water samples were continuously stirred

Table 1. Aqueous samples used to test the EC treatment.

\begin{tabular}{cccc}
\hline Sample & Raw sample & Preparation & Sample obtained for EC treatment \\
\hline A: Zimapan & Turbid water with $[\mathrm{As}]=249.3 \mu \mathrm{g} \cdot \mathrm{L}^{-1}$ & $0.45 \mu \mathrm{m}$ filtration & {$[\mathrm{As}]=61.9 \mu \mathrm{g} \cdot \mathrm{L}^{-1}$} \\
B: Tap water & Water with $[\mathrm{As}]=10 \mu \mathrm{g} \cdot \mathrm{L}^{-1}$ & Addition of $\mathrm{Na}_{2} \mathrm{HAsO}_{4} \cdot 7 \mathrm{H}_{2} \mathrm{O}$ & {$[\mathrm{As}]=500 \mu \mathrm{g} \cdot \mathrm{L}^{-1}$} \\
\hline
\end{tabular}




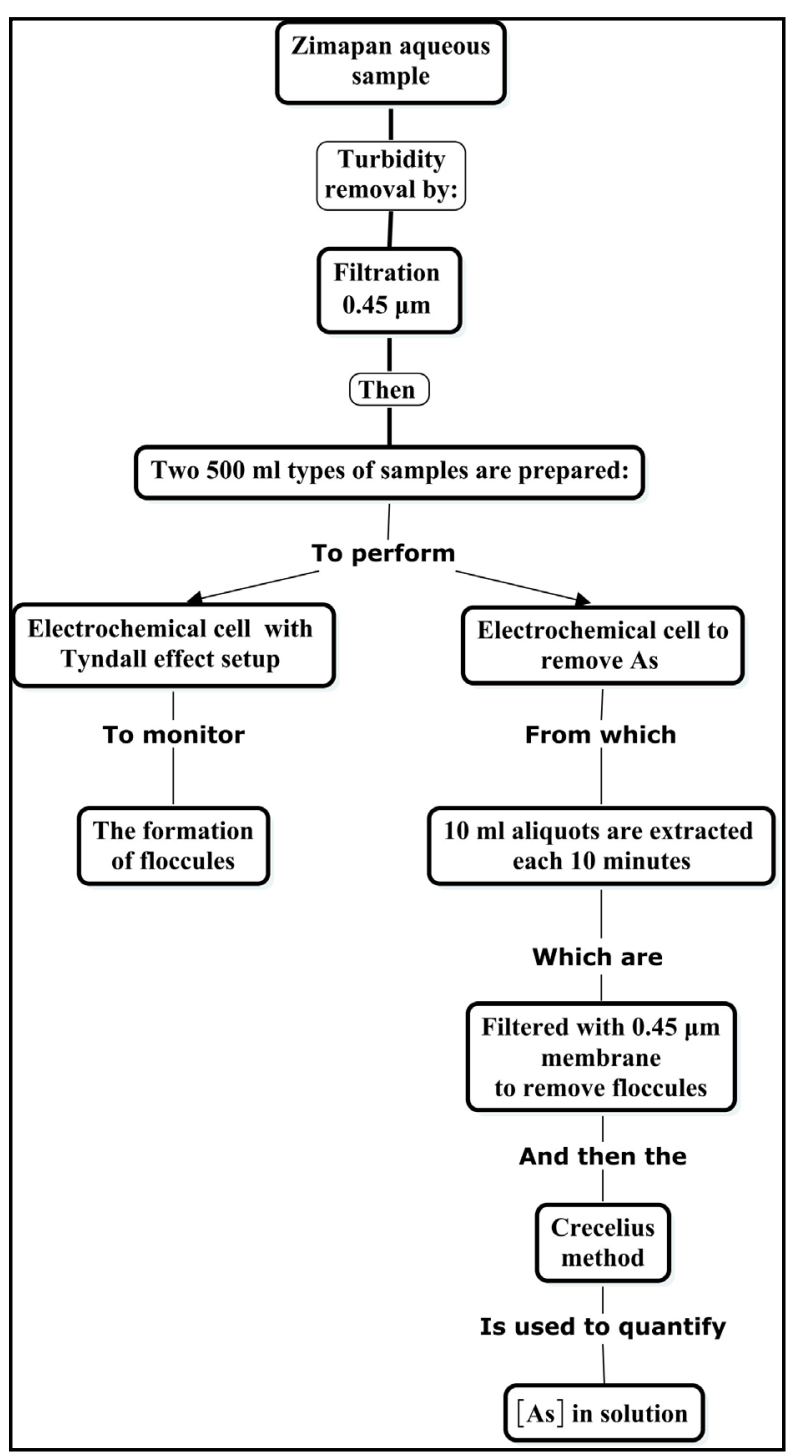

Figure 1. General procedure of the EC method.

and maintained at room temperature $\left(25^{\circ} \mathrm{C}\right)$. During the EC treatment, aliquots of $10 \mathrm{~mL}$ were taken every 10 min. Further, aliquots were filtrated using a Millipore (Billerica, MA, USA) sterile membrane filter (pore size of $0.45 \mu \mathrm{m})$ in order to remove the generated floccules. The $\mathrm{As}^{+5}$ content from filtrated solutions was then quantified as explained below.

At the end of experiments, the remnant solutions in the beaker were filtrated, and the filter was removed using sterile forceps and submitted to digestion process to recover the total arsenic retained. In addition, the final As remnant was also quantified from filtrated solution.

\subsection{Quantification of $\mathrm{As}^{+5}$ in Water Samples}

In order to quantify arsenic concentration of the samples (diluted in water and suspended sediments), the Crecelius method [28], modified and described in Del Razo and coworkers [29] was followed, which consists of the sequential processes shown in Figure 2.

\subsubsection{Sample Preparation}

Aliquots of $10 \mathrm{~mL}$ were taken every 10 minutes from $500 \mathrm{~mL}$ of the water sample submitted to continuous stirring during the EC process in order to determine $\mathrm{As}^{+5}$ concentration. 


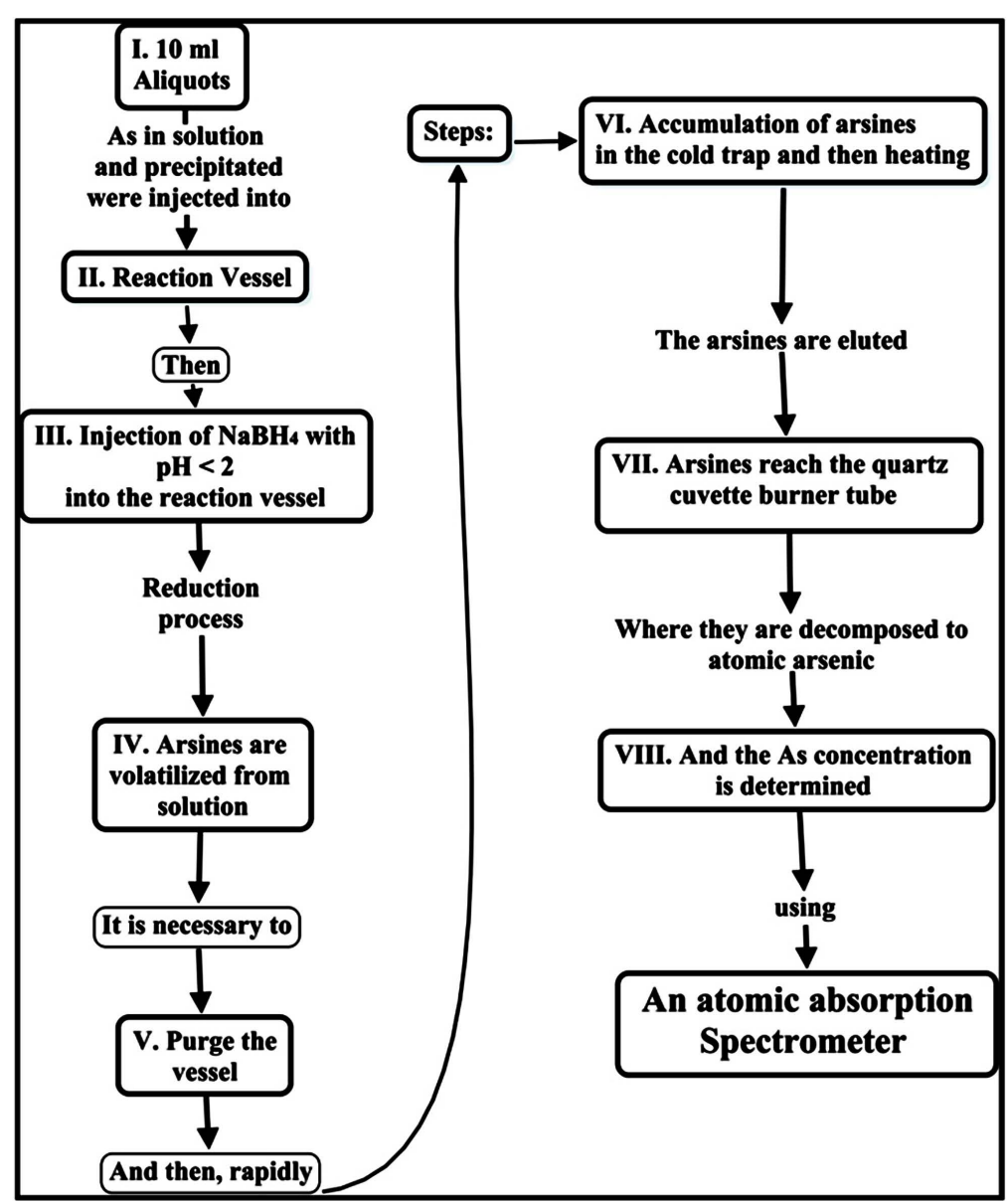

Figure 2. The Crecelius method to quantify $\left[\mathrm{As}^{+5}\right]$.

\subsubsection{Digestion}

Homogenized $10 \mathrm{~mL}$ aliquots taken every 10 minutes were digested with $0.4 \mathrm{~mL}$ of $1: 1 \mathrm{HNO}_{3}$ diluted and $2 \mathrm{~mL}$ 1:1 $\mathrm{HCl}$ diluted. They were placed to reach $90^{\circ} \mathrm{C}$ on a hot plate until the total volume was reduced to $2.5 \mathrm{~mL}$. After this, volume was raised to $10 \mathrm{~mL}$ with deionized water according with the $\mathrm{HNO}_{3} / \mathrm{HCl} 3030 \mathrm{~F}$ digestion procedure for recuperation of As established in standard methods [30].

\subsection{3. $\mathrm{As}^{+5}$ Quantification}

A modified Crecelius and coworkers method [28] described in [29] was followed to quantify As ${ }^{+5}$. All reagents employed were of a ultra-pure degree from Merck. Likewise, acids used were of analytical degree. Once the solution digested was raised to $10 \mathrm{~mL}$ with deionized water, $1 \mathrm{~mL}$ aliquots of each sample were taken and mixed with $10 \mathrm{~mL}$ of deionized water, $1 \mathrm{~mL}$ of $\mathrm{HCl} 6 \mathrm{~N}$. Then, in this solution it was injected $2 \mathrm{~mL}$ of $4 \%$ (weight/ volume) solution of $\mathrm{NaBH}_{4}$ in $\mathrm{NaOH} 0.02 \mathrm{M}$ (weight/volume) in the cylinder of reaction. The total volume injected into the cylinder of reaction was $14 \mathrm{~mL}$.

Once all arsines are generated in an acidic medium ( $\mathrm{pH}=2$ or lower), they are retained in the chromatographic trap immersed in liquid nitrogen, which is gradually warmed to collect separated arsines according with their differences in boiling points. Then, arsines suffer atomization by an air/hydrogen flame in the quartz combustion cell and are converted to elemental arsenic atoms. The releasing arsenic atoms are detected by atomic absorption spectrophotometry (Perkin Elmer model 3100, equipped with an EDL II Perkin-Elmer electrodeless discharge lamp, coupled with a Perkin Elmer integrator, model Nelson) operating at $\lambda=197.3 \pm 0.7 \mathrm{~nm}$ which corresponds to one of the most probable transitions for As.

In order to quantify As from water samples, the next procedures were performed. Working standards of 20 $\mu \mathrm{g} \cdot \mathrm{L}^{-1}$ of As were daily prepared from a stock solution of $1000 \mu \mathrm{g} \cdot \mathrm{L}^{-1}$, whose spectrophotometric curve was 
used as a reference to determine As concentration in the water samples. These standards were prepared triplicate, presenting less than $10 \%$ coefficient of variation accepted by standard methods [30]. To evaluate the accuracy of As content in quantification procedures, it was used the NIST 1640 reference water (National Institute Standards and Technology, Gaithersburg, MD) which had a concentration of $26.67 \pm 0.41 \mathrm{mg} \cdot \mathrm{Kg}^{-1}$. In the standard and NIST water samples, to measure As content, both of them were also submitted to the digestion process before quantification by spectrophotometry. A blank (prepared with both acids, $\mathrm{HNO}_{3}$, and $\mathrm{HCl}$ ) was also prepared as control for reagents, included in each As determination. Once As quantification from NIST water was 99.5\% accuracy, measurements from water samples were carried out.

\subsection{Arsenic Products Quantification and Identification during the EC Process}

Identification of arsenic products of precipitated arsenic was performed through X-ray diffraction crystallography using a diffractometer (Siemens, D5000) equipped with a Cu target tube.

To quantify the products formed during the EC process from ions released by the electrodes, an atomic absorption spectrophotometer with flame (F-AAS) method to measure $\mathrm{Cu}^{2+}$ and $\mathrm{Zn}^{2+}$ arsenic products (Perkin Elmer model 3100 user manual) was used. In summary, samples (from arsenic suspended and diluted) were digested with acid and then nebulized, in a similar arrangement of that used for quantification of As described above, to convert the sample into small particles. Then, the samples (filters and water aliquots) were burned with a flame of air and acetylene in order to separate the compounds in atomic elements. Finally, samples were quantified by spectrophotometry at $\lambda=324.7 \mathrm{~nm}$ for $\mathrm{Cu}^{2+}$ compounds, and at $\lambda=213.8 \mathrm{~nm}$ for $\mathrm{Zn}^{2+}$ compounds. Data obtained were quantified by interpolation in calibration curves according with the user manual.

\subsection{Monitoring Flocculation of As during the EC Process by the Tyndall Effect}

As the EC process produces the formation of particles of $\mathrm{Cu}^{2+}$ and $\mathrm{Zn}^{2+}$ arsenic compounds (flocculates), it is feasible to observe and measure the rate of such particle formation, and provide information about the dynamics of the process. To monitoring the formation of particles in the water samples during the EC process, the Tyndall effect was used (see the experimental setup in Figure 3). The light beam from a He-Ne laser (Melles Griot) with a wavelength $\lambda=632.8 \mathrm{~nm}, 1 \mathrm{~mW}$, is periodically interrupted by an optical chopper (SRI). A lock-in amplifier (SRI, mod. SR530) is tuned to the chopper frequency through the reference channel, which permits the detection of the scattered light through the solution by means of a silicon photodetector (EG \& G). The output is connected to a current-voltage operational amplifier. The photodetector is positioned at $30^{\circ}$ with respect to the beam. The lock-in amplifier is linked to a PC using a GPIB parallel port.

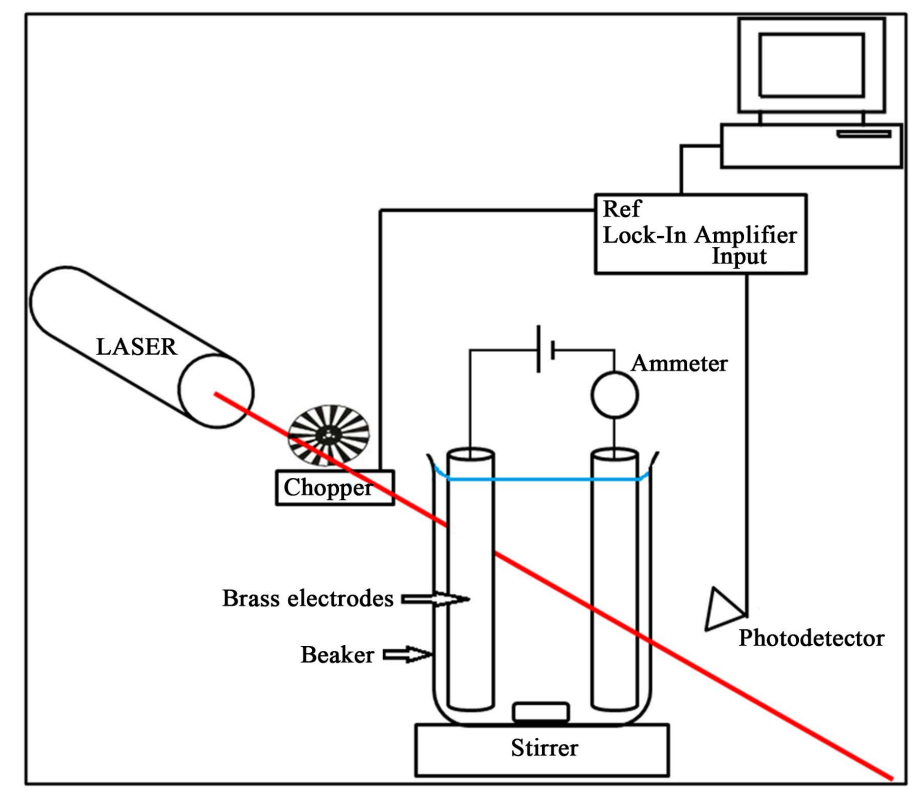

Figure 3. Experimental setup for the Tyndall effect method. 


\section{Results and Discussion}

\subsection{Evolution of $\mathrm{As}^{+5}$ Removal during the EC Process}

In Figure 4 is shown a typical chromatogram of the water of Zimapan before EC (large peak), in which one can observe the evolution time for $\mathrm{As}^{+5}$. In the same figure, it is also shown a chromatogram of water of Zimapan at 10 minutes of EC treatment (small peak). The retention time starts at the moment in which the cold trap begins to be heated. The $\mathrm{As}^{+5}$ concentration is proportional to the area under the peak and above the baseline signal, according to the NIST sample mentioned above for calibration purposes, as mentioned in Materials and Methods section.

In Figure 5 the aqueous arsenate concentration as a function of time in samples A and B are shown. It can be observed that $\mathrm{As}^{+5}$ concentration in Zimapan water diminishes below the detection limit of the equipment between 10 and 20 minutes of EC treatment. Besides, it can also be noted that, for absolute values, the arsenic removal for Zimapan sample is faster than in the tap water sample, as observed in Figure 6. For instance, at ten minutes, the EC method removes $93.54 \%$ of the arsenic content in Zimapan sample (from an initial concentration of $61.9 \mu \mathrm{g} \cdot \mathrm{L}^{-1}$ ) at an average rate of $0.07 \mu \mathrm{g} / \mathrm{sec}$. By contrast, in the tap water sample, $55.84 \%$ of the arsenic (from an initial concentration of $500 \mu \mathrm{g} \cdot \mathrm{L}^{-1}$ ) was removed after 10 minutes of EC treatment at an average rate of $0.4 \mu \mathrm{g} / \mathrm{sec}$. However, it is necessary consider that the initial concentrations in both samples were quite differ-

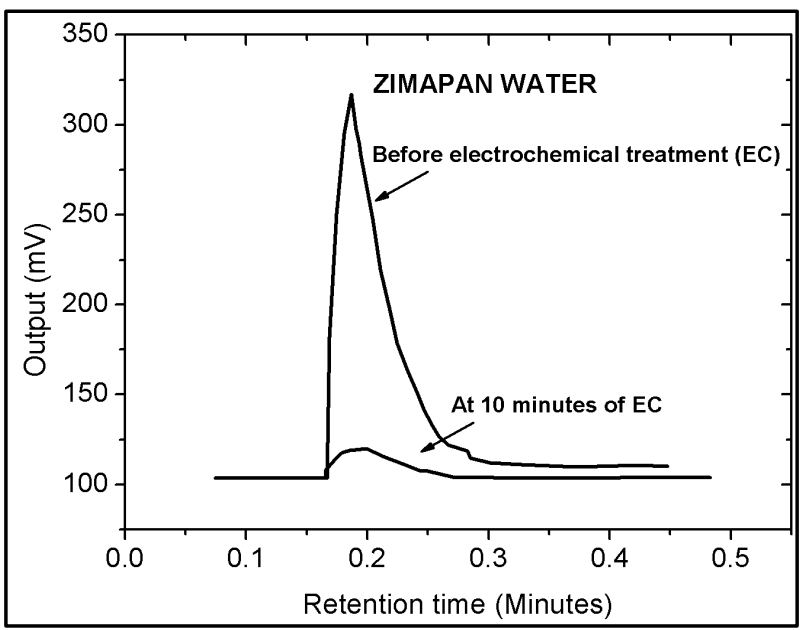

Figure 4. Change of the chromatograms of Zimapan water with the EC treatment.

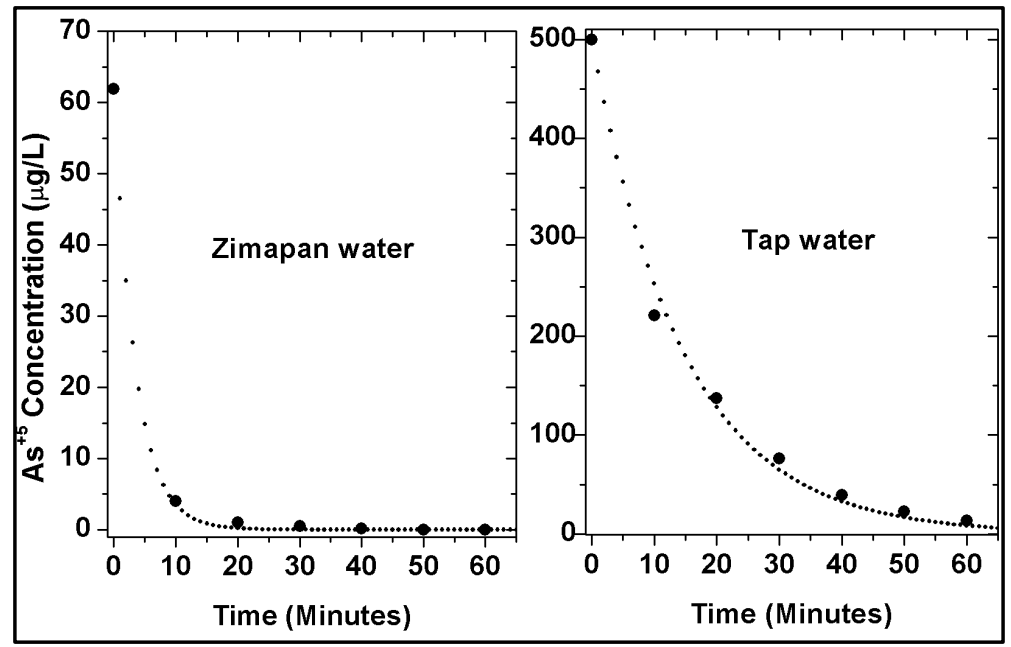

Figure 5. $\mathrm{As}^{+5}$ content in the water samples as a function of the EC treatment. 


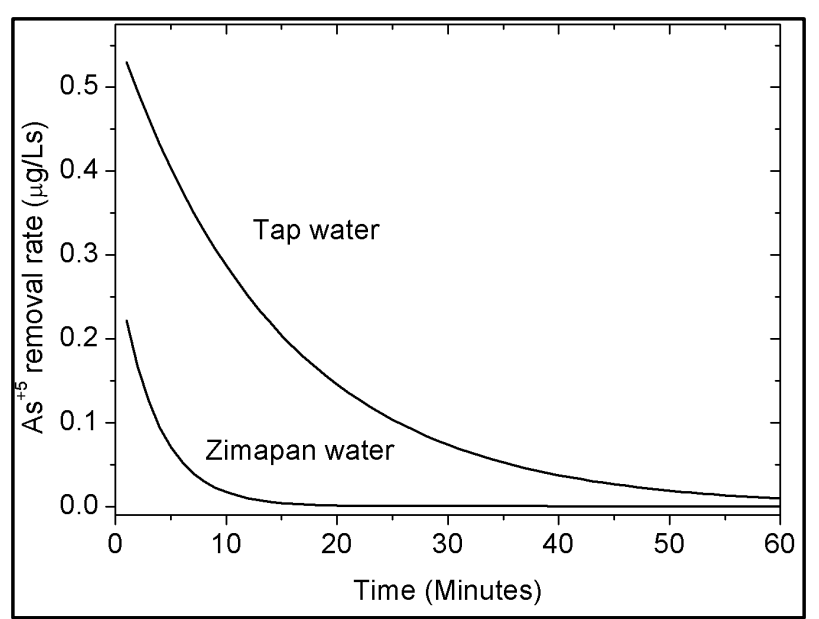

Figure $6 . \mathrm{As}^{+5}$ removal rate obtained from the decaying exponential fitting indicated by the dots in Figure 5.

ent: $61.9 \mu \mathrm{g} \cdot \mathrm{L}^{-1}$ for the Zimapan sample and $500 \mu \mathrm{g} \cdot \mathrm{L}^{-1}$ for the tap water sample. For the Zimapan water sample, it is necessary an elapsed time between 10 and 20 minutes to reach [As] $<1 \mu \mathrm{g} \cdot \mathrm{L}^{-1}$. In contrast, for the tap water sample an hour is needed to diminish [As] to $13 \mu \mathrm{g} \cdot \mathrm{L}^{-1}$. The corresponding theoretical fits for both graphs (Figure 5), were used to establish the rate of arsenic removal during the process (Table 2). From this fit, it was obtained the time in which the concentration of arsenic becomes half of the initial value, namely $t_{1 / 2}$ for each water sample. For the Zimapan sample $t_{1 / 2}=2.43$ minutes (with a removal rate of $0.14 \mu \mathrm{g} / \mathrm{sec}$ ), and for the tap water sample $t_{1 / 2}=10.19$ minutes (at a rate of $0.28 \mu \mathrm{g} / \mathrm{sec}$ ). In fact, the removal of arsenic is faster in the tap water sample than in the Zimapan sample water during the whole process, despite the concentration of arsenic in the tap water sample is higher. Thus, although there is a lower concentration of arsenic in the Zimapan sample, the electrochemical reaction is faster in the tap water.

It is plausible to assume that, despite the arsenic available in both samples diminishes as the EC process takes place, the saturation in the system may occur in an important way when the electrode becomes coated, probably with an oxide surface layer product of the reaction of the electrode components $(\mathrm{Zn}, \mathrm{Cu}$, etc.) and the ions and salts present in the solution. Once the electrode is covered with the coated formed by the own electrode ions and the ions and salts from the solution, the amount of ions of zinc and copper (which are released to the solution), may be reduced progressively as the coat becomes thicker. As a result, since there are less arsenic and less $\mathrm{Cu}^{2+}$ and $\mathrm{Zn}^{2+}$ ions (reactants), the rate of the reaction diminishes to form the products following the law of mass action [31]. This electrochemical effect is the cause of the decrease in the velocity of the removal of arsenic in the tap water sample although it remains enough arsenic available in the solution.

\subsection{Evolution of the Tyndall Effect}

The generated floccules during the EC treatment were monitored by the Tyndall effect, which is proportional to the optical turbidity. According to Figure 7, the light dispersion in the solution increases until saturation is reached after 60 minutes for Zimapan sample and after 80 minutes for tap water sample. The continuous lines represent the logistic fittings to the experimental points, given by the following equation:

$$
Y=A_{2}+\left(A_{1}-A_{2}\right) /\left(1+\left(\frac{t}{t_{01}}\right)^{p}\right) .
$$

The fitting parameters are shown in Table 2.

In Figure 8, it can be seen that in Zimapan sample although the arsenic concentration has been diminished about 95\% at the minute 10 and below $1 \mu \mathrm{g}$ at the minute 20 (Figure 5), turbidity (Figure 7) continues increasing until the minute 60 (in fact, after the minute 10, there is no more arsenic detectable in the Zimapan sample water). After the minute 60 , turbidity increases at a low rate almost reaching asymptotic values. On the other side, in the tap water sample, turbidity only continues growing after the minute 60 at a low rate, time in which 


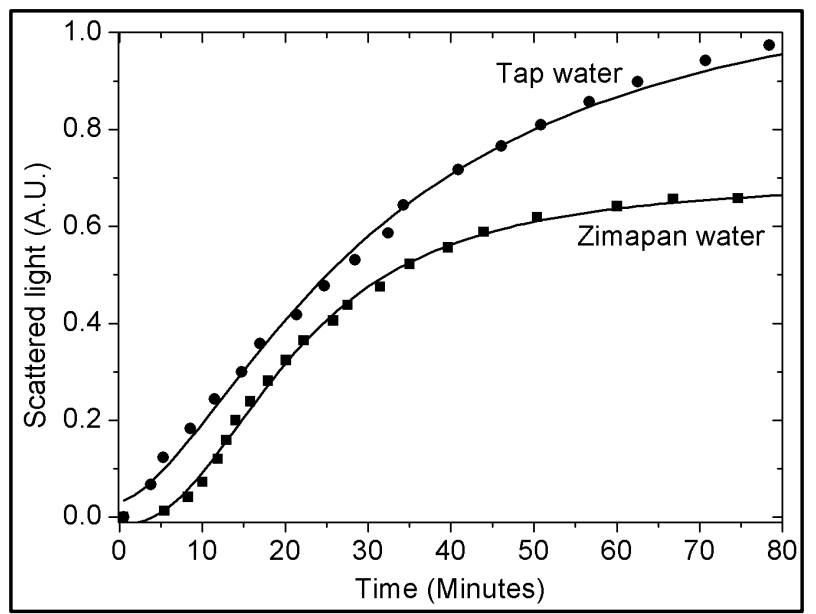

Figure 7. Evolution of the turbidity as a function of the elapsed time for both water samples. The continuous lines result from the fitting to logistic curves, whose fitting parameters are indicated in the turbidity columns of Table 2.

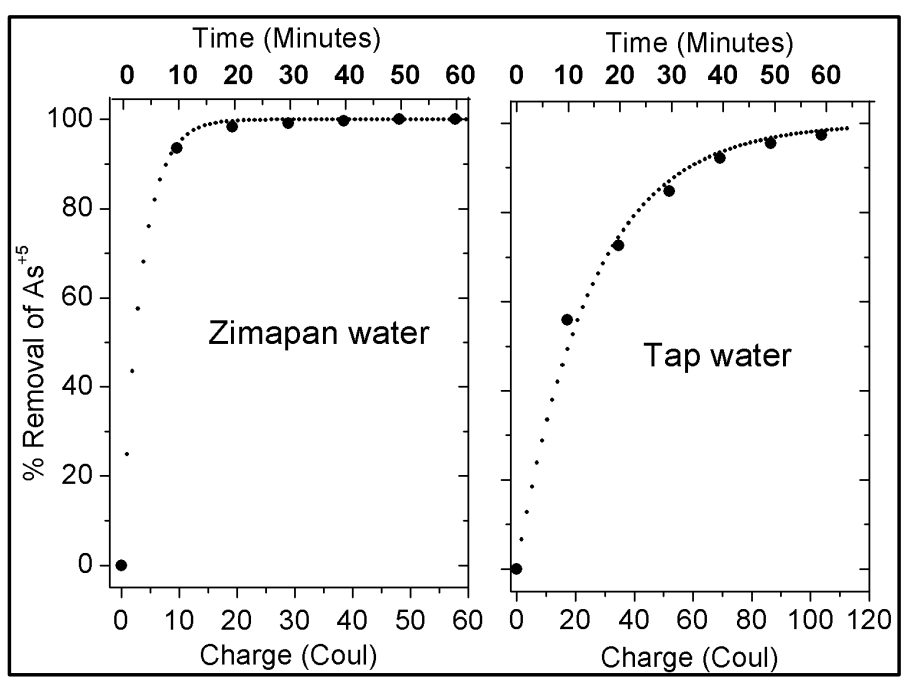

Figure 8. Arsenic percentage removal and charge involved during the EC. Filled large dots correspond to data and small points to exponential fit.

Table 2. Fitting parameters of As concentration $\left(A, t_{0}, t_{1 / 2}\right)$, and turbidity $\left(A_{1}, A_{2}, t_{01}\right.$, and $\left.p\right)$ as a function of time, using a decreasing exponential, and a logistic curve, respectively.

\begin{tabular}{|c|c|c|c|c|c|c|c|c|c|}
\hline \multirow{2}{*}{ Sample } & \multicolumn{5}{|c|}{$[$ As $]=A \exp \left(-t / t_{0}\right)$} & \multicolumn{4}{|c|}{ Turbidity $Y=A_{2}+\left(A_{1}-A_{2}\right) /\left(1+\left(t / t_{01}\right)^{p}\right)$} \\
\hline & $A$ & $t_{0}$ & $t_{1 / 2}$ & $\mathrm{pH}_{\mathrm{i}}$ & $\mathrm{pH}_{\mathrm{f}}$ & $A_{1}$ & $A_{2}$ & $T_{01}$ & $p$ \\
\hline Zimapan & 61.9 & 3.5 & 2.43 & 7.92 & 8.13 & -0.014 & 0.696 & 21.24 & 2.306 \\
\hline Tap water & 500 & 14.7 & 10.19 & 7.30 & 7.90 & 0.033 & 1.165 & 31.32 & 1.58 \\
\hline
\end{tabular}

remains $13.5 \mu \mathrm{g}$ of arsenic in the water (Figure 5).

It is possible that the $\mathrm{pH}$ is involved, at least in some extent: the change in $\mathrm{pH}$ before and after the EC treatment (Table 2). At the beginning of the EC process, the Zimapan sample water has a $\mathrm{pH}=7.92$ and the tap water sample a $\mathrm{pH}=7.30$, a difference of 0.62. Consider, for instance, the change in $\mathrm{pH}$ for the Zimapan water sample, i.e., $\Delta_{\mathrm{pHZimapan}}=+0.21$, and the change in $\mathrm{pH}$ for the tap water sample, i.e., $\Delta_{\mathrm{pHTapWater}}=+0.6$. The slight 
higher acidity of the tap water sample before and after the EC process could have generated a slightly more detachment of ions, $\mathrm{Cu}^{2+}$ and $\mathrm{Zn}^{2+}$, from the brass electrode, giving rise to an increase of the As removal from the solution.

The analysis of the filtered sediments obtained from the EC treatment analyzed by EDS, revealed the presence of $50.07 \% \mathrm{Zn}, 3.9 \% \mathrm{Cu}, 29.42 \% \mathrm{O}, 0.64 \% \mathrm{Ca}, 3.71 \% \mathrm{As}$, and $9.09 \% \mathrm{Si}$, as shown in Table 3 . Table 3 and Table 4 display the identification of the main peaks, which were obtained taking into account the elemental analysis by EDS previously mentioned and the database of the XRD system. The crystallographic phases of the precipitates were identified by X-ray diffraction. In Figure 9 the XRD spectra for both samples are shown. The spectra reveal nanometric and/or micrometric structures in an amorphous background.

\subsection{Energy Consumption during the Arsenic Removal Process}

It is worth to indicate that it is useful to describe the evolution of the removal of Arsenic by plotting the content of arsenic as a function of the electric charge through the solution.

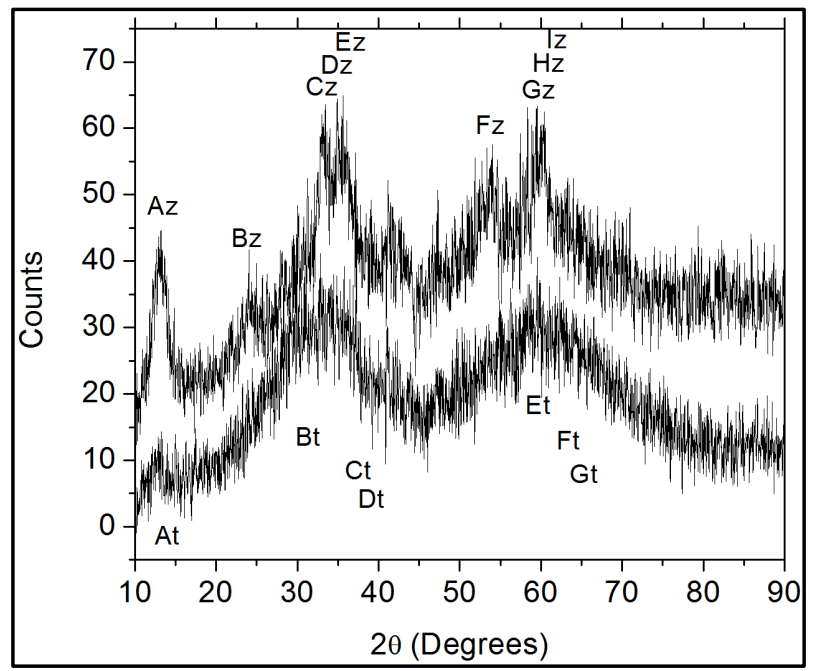

Figure 9. X-Ray diffractograms for sediments of sample A (Zimapan water whose features are labeled with $z$ ), and for sample B (Tap water, whose features are labeled with $t$ ).

Table 3. Identification of XRD main peaks of sediments obtained from Zimapan water (sample A).

\begin{tabular}{|c|c|c|c|c|c|}
\hline Peak & Position $(2 \theta)$ & Compound & Structure & Planes & JCPDS-ICDD file \\
\hline $\mathrm{Az}$ & 13.164 & $\begin{array}{c}\mathrm{Zn}_{3}\left(\mathrm{AsO}_{4}\right)_{2} \cdot 8 \mathrm{H}_{2} \mathrm{O} \\
\text { Kottigite }\end{array}$ & Monoclinic & 020 & $33-1467$ \\
\hline $\mathrm{Bz}$ & 24.907 & $\begin{array}{c}\mathrm{ZnCO}_{3} \\
\text { Smithsonite }\end{array}$ & Rombohedric & $\begin{array}{l}004 \\
202\end{array}$ & $8-449$ \\
\hline $\mathrm{Cz}$ & 30.569 & $\begin{array}{l}\mathrm{Zn}(\mathrm{OH})_{2} \\
\text { Sweetite }\end{array}$ & Tetragonal & $\begin{array}{l}213 \\
220\end{array}$ & $38-356$ \\
\hline $\mathrm{Dz}$ & 34.412 & $\mathrm{Ca}_{3} \mathrm{SiO}_{5}$ & Monoclinic & 225 & $42-551$ \\
\hline $\mathrm{Ez}$ & 34.994 & $\begin{array}{c}\mathrm{Cu}_{5}\left(\mathrm{AsO}_{4}\right)_{2}(\mathrm{OH})_{4} \\
\text { Cornubite }\end{array}$ & Triclinic & 212 & $38-441$ \\
\hline $\mathrm{Fz}$ & 52.210 & $\mathrm{Co}_{2} \mathrm{O}_{3}$ & Hexagonal & 203 & $02-770$ \\
\hline $\mathrm{Gz}$ & 58.559 & $\begin{array}{c}\mathrm{Cu}_{5}\left(\mathrm{AsO}_{4}\right)_{2}(\mathrm{OH})_{4} \\
\text { Cornubite }\end{array}$ & Triclinic & 014 & $38-441$ \\
\hline $\mathrm{Hz}$ & 60.720 & $\begin{array}{c}\mathrm{Cu}_{5}\left(\mathrm{AsO}_{4}\right)_{2}(\mathrm{OH})_{4} \\
\text { Cornubite }\end{array}$ & Triclinic & $\begin{array}{l}212 \\
412\end{array}$ & $38-441$ \\
\hline $\mathrm{Iz}$ & 61.119 & $\begin{array}{c}\mathrm{Cu}_{5}\left(\mathrm{AsO}_{4}\right)_{2}(\mathrm{OH})_{4} \\
\text { Cornubite }\end{array}$ & Triclinic & 221 & $38-441$ \\
\hline
\end{tabular}


Table 4. Identification of XRD main peaks of sediments obtained from Tap water (sample B).

\begin{tabular}{|c|c|c|c|c|c|}
\hline Peak & Position $(2 \theta)$ & Compound & Structure & Planes & JCPDS-ICDD file \\
\hline At & 13.164 & $\begin{array}{c}\mathrm{Zn}_{3}\left(\mathrm{AsO}_{4}\right)_{2} \cdot 8 \mathrm{H}_{2} \mathrm{O} \\
\text { Kottigite }\end{array}$ & Monoclinic & 020 & $33-1467$ \\
\hline $\mathrm{Bt}$ & 30.569 & $\begin{array}{l}\mathrm{Zn}(\mathrm{OH})_{2} \\
\text { Sweetite }\end{array}$ & Tetragonal & $\begin{array}{l}213 \\
220\end{array}$ & $38-356$ \\
\hline $\mathrm{Ct}$ & 34.412 & $\mathrm{Ca}_{3} \mathrm{SiO}_{5}$ & Monoclinic & 225 & $42-551$ \\
\hline Dt & 34.994 & $\begin{array}{c}\mathrm{Cu}_{5}\left(\mathrm{AsO}_{4}\right)_{2}(\mathrm{OH})_{4} \\
\text { Cornubite }\end{array}$ & Triclinic & 212 & $38-441$ \\
\hline Et & 58.559 & $\begin{array}{c}\mathrm{Cu}_{5}\left(\mathrm{AsO}_{4}\right)_{2}(\mathrm{OH})_{4} \\
\text { Cornubite }\end{array}$ & Triclinic & 212 & $38-441$ \\
\hline $\mathrm{Ft}$ & 60.720 & $\mathrm{Co}_{2} \mathrm{O}_{3}$ & Triclinic & 212 & $38-441$ \\
\hline Gt & 61.119 & $\begin{array}{c}\mathrm{Cu}_{5}\left(\mathrm{AsO}_{4}\right)_{2}(\mathrm{OH})_{4} \\
\text { Cornubite }\end{array}$ & Triclinic & 212 & $38-441$ \\
\hline
\end{tabular}

Thus, the amount of electric charge that passes through the electrodes is given by the equation:

$$
Q(t)=\int_{0}^{t} I\left(t^{\prime}\right) d t^{\prime}
$$

where $I\left(t^{\prime}\right)$ is the electrical current (in the SI units ampere, A) monitored while the aqueous sample is EC treated.

In the case of Zimapan water a constant current has been observed:

$$
I(t)=0.016 \mathrm{~A}
$$

And for the tap water:

$$
\begin{aligned}
& I(t)=A_{1} e^{-t / t_{1}}+y_{0} . \\
& \text { where } \\
& A_{1}=0.0072 \mathrm{~A} . \\
& t_{1}=686.87 \mathrm{sec} . \\
& y_{0}=0.027 \mathrm{~A} .
\end{aligned}
$$

Thus, the total charge involved during the EC process was 19.2 Coulomb after 20 minutes in which arsenic diminishes from $61.9 \mu \mathrm{g} \cdot \mathrm{L}^{-1}$ to $<1 \mu \mathrm{g} \cdot \mathrm{L}^{-1}$ for Zimapan sample, and 102.12 Coulombs for the tap water sample after 60 minutes of the experiment in which the arsenic concentration was reduced to $13.5 \mu \mathrm{g} \cdot \mathrm{L}^{-1}$.

For the Zimapan water sample, the consumed energy to remove arsenic below the limits of detection of the equipment was of 57.6 Joules, while in the tap water sample was 291.6 Joules, to diminish to $13.5 \mu \mathrm{g} \cdot \mathrm{L}^{-1}$.

The energy cost to remove a $\mu \mathrm{g}$ of As is 0.93 Joules for the Zimapan sample while that corresponding to the tap water sample is 0.58 Joules.

\subsection{Chemical Reactions Carried out during the EC Process}

In the treatment of arsenic-contaminated water, chemical reactions initiate the nucleation of particles susceptible to be monitored during the EC method by the Tyndall effect. The reactions carried out during the EC process, which produces light scattering floccules are described in the scheme shown in Figure 10.

In the EC method, the electrodes play a fundamental role since they are the source of $\mathrm{Zn}$ and $\mathrm{Cu}$ ions, which form solid complexes with arsenic ions, through oxidation-reduction reactions, to form compounds that grow into floccules that are easy to eliminate from the water. The electrodes exposed to the water solutions can be dissolved or corroded due to the electrode or corrosion potential, which is determined by the equilibrium between the reactions that occur in the anode and the cathode surface. Through the anodic reaction, the anode oxidizes and, thus, corrodes. By applying an electrical potential to the metal surface between the electrodes, this process can be altered [32]. Since zinc and copper are the main elements of brass electrodes, they corrode both in acidic and alkaline solutions, but resist corrosion well in neutral solutions [32]. 


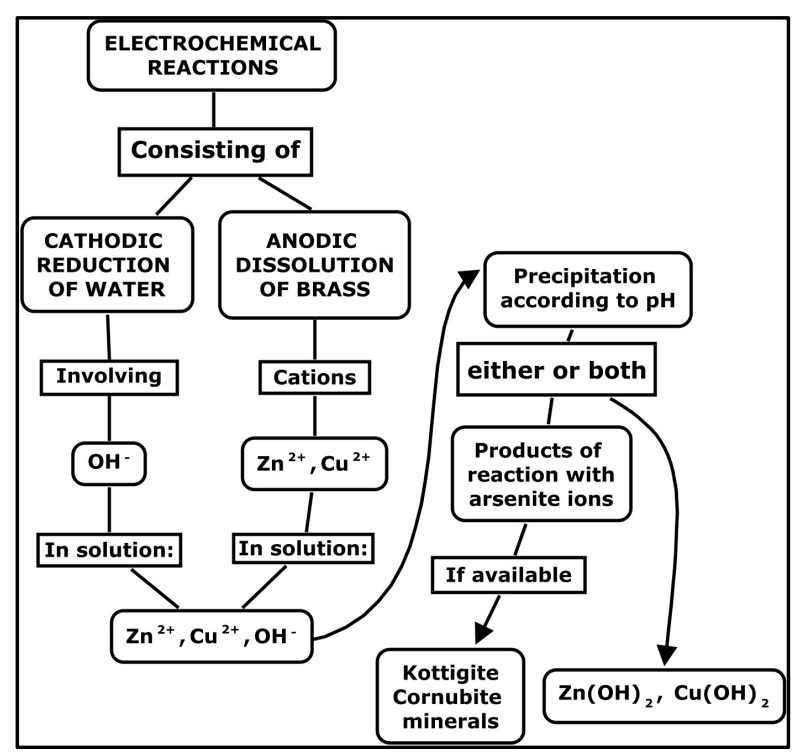

Figure 10. Formation of light scattering particles precipitated or floccules during the EC treatment. In fact, the light dispersive particles are the mineral compounds containing As and the precipitated hydroxides.

The corresponding anodic reactions of the brass electrodes that take place in the EC method $(\mathrm{pH}>7)$ used are:

$$
\begin{aligned}
& \mathrm{Zn} \rightarrow \mathrm{Zn}^{2+}+2 \mathrm{e}^{-} \\
& \mathrm{Cu} \rightarrow \mathrm{Cu}^{2+}+2 \mathrm{e}^{-}
\end{aligned}
$$

Also, in the cathode region the water molecule is reduced to produce hydrogen and hydroxyl ions:

$$
2 \mathrm{H}_{2} \mathrm{O}+2 \mathrm{e}^{-} \rightarrow \mathrm{H}_{2}+2 \mathrm{OH},
$$

but the hydrogen ions are not enough to generate hydrogen gas. However, there are too many electrons in the brass electrodes reacting with oxygen molecules, which were adsorbed by the metal surface from the air dissolved in the water samples, to produce the hydroxyl ions. Such hydroxyl ions form a precipitate with the $\mathrm{Zn}^{2+}$ and $\mathrm{Cu}^{2+}$ ions since the $\mathrm{pH}$ of the samples are in the range of precipitation of zinc and copper hydroxide [33]:

$$
\begin{aligned}
& \mathrm{Zn}^{2+}+2 \mathrm{OH}^{-} \rightarrow \mathrm{Zn}(\mathrm{OH})_{2} \\
& \mathrm{Cu}^{2+}+2 \mathrm{OH}^{-} \rightarrow \mathrm{Cu}(\mathrm{OH})_{2} .
\end{aligned}
$$

These precipitates could be part of the light scattering particles monitored by the Tyndall effect (see Section 2.5). If there are arsenate ions, the following reaction may take place:

$$
\mathrm{OH}^{-}+\left(\mathrm{HAsO}_{4}\right)^{3-} \rightarrow \mathrm{H}_{2} \mathrm{O}+\left(\mathrm{AsO}_{4}\right)^{3-}
$$

Thus, according with the identified precipitates, the $\mathrm{Zn}^{2+}$ ions may combine with the arsenates ions:

$$
\left(\mathrm{AsO}_{4}\right)^{3-}+\mathrm{Zn}^{2+} \rightarrow \mathrm{Zn}_{3}\left(\mathrm{AsO}_{4}\right)_{2} \text {. }
$$

In the characterization process, this product resulted to be a mineral of kottigite. Also, combining $\mathrm{Cu}^{2+}$ and $\mathrm{OH}^{-}$ions may also produce cornubite mineral as follows:

$$
5 \mathrm{Cu}^{2+}+4 \mathrm{OH}^{-}+2 \mathrm{AsO}_{4}^{3-} \rightarrow \mathrm{Cu}_{5}\left(\mathrm{AsO}_{4}\right)_{2}(\mathrm{OH})_{4}
$$

Comparing these reactions with the results showed in Table 3 and Table 4 from the Section 3.2, it can be observed that the reaction products numbered 8,11 , and 12 , are the corresponding products determined by XRD precipitate analysis. Also, in the precipitate analysis it was found a tiny amount of $\mathrm{Cu}$ in solution. It is possible that, for this reason, the precipitate of $\mathrm{Cu}(\mathrm{OH})_{2}$ could not be detected. 


\section{Conclusions}

In this work, an electrochemical process with brass and monitored by the Tyndall effect has been reported as a method to remove As from contaminated water. The method consists in the electro-flocculation of mineral salts including arsenate ions already present in the water samples with the anodic dissolution of the brass electrodes of $\mathrm{Cu}^{2+}$ and $\mathrm{Zn}^{2+}$ ions, and a final filtration process to separate the floccules from the water. By means of the EC method, it was possible to reduce the arsenic concentration of natural and artificially contaminated water to levels within the limits permitted by the WHO.

The flocculation products were analyzed by EDS, allowing the identification of the corresponding phases by means of X-Ray diffraction. Components of kottigite and cornubite mineral were identified. In addition, the relevant chemical reactions that produced such minerals were proposed and corroborated by analyzing their respective structures consisting of nanometric and/or micrometric sediments in an amorphous background.

The removal rate of arsenic by means of the EC process was higher in the tap water sample artificially contaminated with $500 \mu \mathrm{g} / \mathrm{L}$ of As than in the Zimapan water sample contaminated with $61.9 \mu \mathrm{g} / \mathrm{L}$. The energy cost to remove $1 \mu \mathrm{g}$ of As is 0.93 Joules for the Zimapan sample while that corresponding to the tap water sample is 0.58 Joules.

\section{Acknowledgements}

One of the authors, J.J.G.N. wishes to thank to CONACYT Mexico for the economic support to G.O.L.R. under grant 132432. The participation of Ana Bertha Soto and Marcela Guerrero in the EDS and XRD experiments, respectively, is acknowledged.

\section{References}

[1] Reimann, C., Matschullat, J., Birke, M. and Salminen, R. (2009) Arsenic Distribution in the Environment: The Effects of Scale. Applied Geochemistry, 24, 1147-1167. http://dx.doi.org/10.1016/j.apgeochem.2009.03.013

[2] Matschullat, J. (2000) Arsenic in the Geosphere. A Review. The Science of the Total Environment, 249, $297-312$. http://dx.doi.org/10.1016/S0048-9697(99)00524-0

[3] WHO (2001) Arsenic Compounds, Environmental Health Criteria 224. 2nd Edition, World Health Organization, Geneva.

[4] Smedley, P.L. and Kinniburgh, D.G. (2002) A Review of the Source, Behavior and Distribution of Arsenic in Natural Waters. Applied Geochemistry, 17, 517-568. http://dx.doi.org/10.1016/S0883-2927(02)00018-5

[5] Bissen, M. and Frimmel, F.H. (2003) Arsenic-A Review. Part I: Occurrence, Toxicity, Speciation, Mobility. Acta Hydrochimica et Hydrobiologica, 31, 9-18. http://dx.doi.org/10.1002/aheh.200390025

[6] Villaescusa, I. and Bollinger, J.C. (2008) Arsenic in Drinking Water: Sources, Occurrence and Health Effects (a Review). Reviews in Environmental Science and Biotechnology, 7, 307-323. http://dx.doi.org/10.1007/s11157-008-9138-7

[7] Litter, M.I., Alarcón-Herrera, M.T., Arenas, M.J., Armienta, M.A., Avilés, M., Cáceres, R.E., Nery Cipriani, H., Cornejo, L., Dias, L.E., Fernández Cirelli, A., Farfán, E.M., Garrido, S., Lorenzo, L., Morgada, M.E., Olmos-Márquez, M.A. and Pérez-Carrera, A. (2012) Small-Scale and Household Methods to Remove Arsenic from Water for Drinking Purposes in Latin America. Science of the Total Environment, 429, 107-122. http://dx.doi.org/10.1016/j.scitotenv.2011.05.004

[8] Ötleş, S. and Çağındı, Ö. (2010) Health Importance of Arsenic in Drinking Water and Food. Environmental Geochemistry and Health, 32, 367-371. http://dx.doi.org/10.1007/s10653-010-9296-8

[9] Ng, J.C., Wang, J. and Shraim, A. (2003) A Global Health Problem Caused by Arsenic from Natural Sources. Chemosphere, 52, 1353-1359. http://dx.doi.org/10.1016/S0045-6535(03)00470-3

[10] Duker, A.A., Carranza, E.J.M. and Hale, M. (2005) Arsenic Geochemistry and Health. Environment International, 31, 631-641. http://dx.doi.org/10.1016/j.envint.2004.10.020

[11] Petrusevski, B., Sharma, S., Schippers, J.C. and Shordt, K. (2007) Arsenic in Drinking Water. Delft: IRC International Water and Sanitation Center, 17, 36-44.

[12] Neubauer, O. (1947) Arsenical Cancer: A Review. British Journal of Cancer, 1, 192-251. http://dx.doi.org/10.1038/bjc.1947.22

[13] Cantor, K.P. (1997) Drinking Water and Cancer. Cancer Causes \& Control, 8, 292-308. http://dx.doi.org/10.1023/A:1018444902486

[14] Rossman, T.G. (2003) Mechanism of Arsenic Carcinogenesis: An Integrated Approach. Mutation Research, 533, 37-65. 
http://dx.doi.org/10.1016/j.mrfmmm.2003.07.009

[15] Liu, J. and Waalkes, M.P. (2008) Liver Is a Target of Arsenic Carcinogenesis. Toxicological Sciences, 105, $24-32$. http://dx.doi.org/10.1093/toxsci/kfn120

[16] Smedley, P. and Kinniburgh, D.G. (2005) Arsenic in Groundwater and the Environment. In: Selinus, O., Ed., Essentials of Medical Geology, Elsevier, Amsterdam, 263-299.

[17] U.S. Environmental Protection Agency (1975) Interim Primary Drinking Water Standards. Federal Register, 40, 990.

[18] Ravenscroft, P. (2007) The Global Dimensions of Arsenic Pollution of Groundwater. Tropical Agriculture Association, 27, 3-7.

[19] Ravenscroft, P., Brammer, H. and Richards, K.S. (2009) Arsenic Pollution: A Global Synthesis. Wiley-Blackwell, Hoboken.

[20] Camacho, L.M., Gutiérrez, M., Alarcón-Herrera, M.T., Villalba, M.D.L. and Deng, S. (2011) Occurrence and Treatment of Arsenic in Groundwater and Soil in Northern Mexico and Southwestern USA. Chemosphere, 83, 211-225. http://dx.doi.org/10.1016/j.chemosphere.2010.12.067

[21] Armienta, M.A. and Segovia, N. (2008) Arsenic and Fluoride in the Groundwater of Mexico. Environmental Geochemistry and Health, 30, 345-353. http://dx.doi.org/10.1007/s10653-008-9167-8

[22] Smith, A.H., Lopipero, P.A., Bates, M.N. and Steinmaus, C.M. (2002) Arsenic Epidemiology and Drinking Water Standards. Science, 296, 2145-2146. http://dx.doi.org/10.1126/science.1072896

[23] Armienta, M.A., Rodriguez, R. and Cruz, O. (1997) Arsenic Content in Hair of People Exposed to Natural Arsenic Polluted Groundwater at Zimapan, Mexico. Bulletin of Environmental Contamination and Toxicology, 59, 583-589. http://dx.doi.org/10.1007/s001289900519

[24] INEGI (2010) México en cifras, Hidalgo, Zimapán. http://www.inegi.org.mx/movil/MexicoCifras/mexicoCifras.aspx?em=13084\&i=e

[25] Akter, K.F., Owens, G., Davey, D.E. and Naidu, R. (2005) Arsenic Speciation and Toxicity in Biological Systems. Springer, New York, 97-149.

[26] Lubin, J.H., Freeman, L.E.B. and Cantor, K.P. (2007) Inorganic Arsenic in Drinking Water: An Evolving Public Health Concern. Journal of the National Cancer Institute, 99, 906-907. http://dx.doi.org/10.1093/jnci/djm012

[27] Sarkar, S., Greenleaf, J.E., Gupta, A., Uy, D. and SenGupta, A.K. (2012) Sustainable Engineered Processes to Mitigate the Global Arsenic Crisis in Drinking Water: Challenges and Progress. Annual Review of Chemical and Biomolecular Engineering, 3, 497-517. http://dx.doi.org/10.1146/annurev-chembioeng-062011-081101

[28] Crecelius E.A., Bloom N.S., Cowan, C.E. and Jenne, E.A. (1986) Determination of Arsenic Species in Limnological Samples by Hydride Generation Atomic Absorption Spectroscopy. In: Speciation of Selenium and Arsenic in Natural Waters and Sediments, Vol. 2, Arsenic Speciation, Electric Power Research Institute, Palo Alto, EA-4641, Project 2020-2, 1-28.

[29] Del Razo, L.M., Styblo, M., Cullen, W.R. and Thomas, D.J. (2001) Determination of Trivalent Methylated Arsenicals in Biological Matrices. Toxicology and Applied Pharmacology, 174, 282-293. http://dx.doi.org/10.1006/taap.2001.9226

[30] American Public Health Association, 1989.

[31] Koudriavtsev, A., Jameson, R.F. and Linert, W. (2001) The Law of Mass Action. Springer, Berlin, 328 p. http://dx.doi.org/10.1007/978-3-642-56770-4

[32] Groysman, A. (2010) Corrosion for Everybody. Springer, Israel, 377 p. http://dx.doi.org/10.1007/978-90-481-3477-9

[33] Ayres, D.M., Davis, A.P. and Gletka, P.M. (1994) Removing Heavy Metals from Wastewaters. Engineering Research Center Report, University of Maryland, College Park. 